\title{
Emergence agitation in children after sevoflurane anaesthesia: a comparative evaluation of ketamine and varying doses of fentanyl
}

\author{
D Thomas ${ }^{1}$ *J Lagoo $^{2}$, K Kilpadi ${ }^{3}$ \\ Postgraduate student ${ }^{1}$, Assistant Professor ${ }^{2}$, Professor ${ }^{3}$, Department of Anaesthesiology, St. John's \\ Medical College Hospital, Hosur Road, Bengaluru, Karnataka, India.
}

*Corresponding author: geetjui@gmail.com

\begin{abstract}
Introduction:
Sevoflurane, inhalational anaesthetic of choice in children, is associated with high incidence of emergence agitation (EA). But that "one drug" which can significantly reduce or prevent EA still eludes us. Thus we aimed at studying the efficacy of intravenous ketamine and varying doses of intravenous fentanyl on postoperative emergence agitation in children receiving sevoflurane anaesthesia.
\end{abstract}

\begin{abstract}
Materials and methods:
This prospective, double blind, randomized comparative study was conducted on 114 children, 210 years, with ASA physical status I-II. They were undergoing herniotomy under sevoflurane anaesthesia and were randomly divided into Group A receiving ketamine $0.5 \mathrm{mg} / \mathrm{kg}$, Group B fentanyl $2 \mathrm{mcg} / \mathrm{kg}$ and Group $\mathrm{C}$ fentanyl $3 \mathrm{mcg} / \mathrm{kg}$ at the time of induction. Postoperatively emergence agitation was assessed every 5 min during first 60 min of PACU stay using Aono's four point scale. We also observed recovery characteristics including time to extubation, time to emergence, discharge from PACU and postoperative complications.

Results: The incidence of EA was significantly low in Group A (31.6\%) and Group C (28.9\%) compared to group B (65.8\%), with no significant difference between Group A and Group C. Incidence of EA was higher in preschool children. A prolonged PACU stay was observed in all children who developed EA, with lesser duration of PACU stay noted in fentanyl $3 \mathrm{mcg} / \mathrm{kg}$ group. Conclusion: Intravenous administration of either ketamine $0.5 \mathrm{mg} / \mathrm{kg}$ or fentanyl $3 \mathrm{mcg} / \mathrm{kg}$ i.v. at the time of induction reduces the incidence of EA effectively when compared with fentanyl $2 \mathrm{mcg} / \mathrm{kg}$, without delaying recovery.
\end{abstract}

Keywords: emergence agitation; sevoflurane; ketamine; fentanyl

\section{Introduction}

Emergence Agitation (EA) is an undesirable state frequently associated with sevoflurane anaesthesia with an incidence of $10-50 \%$, with an incidence of up to $80 \%$ in children. ${ }^{1,2}$

It may cause injury to child or surgical site, accidental removal of dressings, catheters and drains requiring extra nursing care as well as supplemental medications, delaying the discharge $^{1}$ leading to dissatisfaction with the quality of anaesthesia.

Despite studies conducted with various drugs, that "one drug" which will significantly reduce or prevent EA in children still eludes us. Thus, we undertook this study with the primary objective to study and compare the efficacy of intravenous ketamine and varying doses of intravenous fentanyl on emergence agitation in children receiving sevoflurane anaesthesia. We also observed the recovery characteristics including time to extubation, time to discharge from PACU and incidence of postoperative nausea and vomiting.

\section{Material and Methods}

After obtaining the approval of the hospital ethical committee and informed written consent from parents, this prospective, double blind, randomized controlled study was conducted on 114 children, aged 2-10 years, with ASA physical status I-II, scheduled to undergo herniotomy. The exclusion criteria were history of snoring, sleep apnoea, cognitive or developmental disorders, 
seizure disorder, hypersensitivity to study drugs, and agitation during induction.

The children were randomly allocated to three groups of 38 each. Group A received ketamine $0.5 \mathrm{mg} / \mathrm{kg}$, Group B received fentanyl $2 \mathrm{mcg} / \mathrm{kg}$, Group C received fentanyl $3 \mathrm{mcg} / \mathrm{kg}$ intravenously.

Anaesthesia protocol was standardized. All children were fasted 6 hours for solid food and 2 hours for clear liquids preoperatively. One parent was allowed to accompany the child into the preoperative holding area.

Anaesthesia was induced with incremental concentration of sevoflurane in $100 \%$ oxygen through facemask. After securing intravenous access, patients were given $0.01 \mathrm{mg} / \mathrm{kg}$ glycopyrrolate and $0.1 \mathrm{mg} / \mathrm{kg}$ ondansetron intravenously and the study drug was administered. Electrocardiogram, capnography and pulse oximetry were monitored.

Anaesthesia was maintained with $50 \% \mathrm{O}_{2}$, nitrous oxide, sevoflurane and atracurium to facilitate tracheal intubation. Analgesia was administered with a caudal block with $0.25 \%$ bupivacaine, diclofenac sodium suppository $1.5 \mathrm{mg} / \mathrm{kg}$ and paracetamol suppository $20 \mathrm{mg} / \mathrm{kg}$.

At the end of surgery, neuromuscular blockade was reversed with neostigmine $0.05 \mathrm{mg} / \mathrm{kg}$ and glycopyrrolate $0.01 \mathrm{mg} / \mathrm{kg}$. The tracheal tube was removed after the return of sufficient spontaneous breathing, gag reflex and purposeful movements.

The time to extubation defined as time from the end of surgery to tracheal extubation, and emergence time as the time of first response to command or eye opening on command after extubation were recorded. The time between the surgical incision and the end of surgery was recorded as the duration of surgery, whereas, the time from the attachment of the basic monitors until the extubation time was recorded as the duration of anaesthesia.

On admission to the post-anaesthesia care unit (PACU), all patients were observed for $60 \mathrm{~min}$. EA was assessed every 5 min using Aono's four point scale
(1) Asleep

(2) Awake but calm

(3) Agitated but consolable

(4) Severely agitated and difficult to console.

The highest-recorded value was noted during the PACU stay. Grades 1 and 2 were considered as no agitation and grades 3 and 4, lasting for more than or equal to 5 minutes as emergence agitation. Midazolam $0.02-0.1 \mathrm{mg} / \mathrm{kg}$ was given as a rescue medication.

Incidence of adverse events such as respiratory depression, oxygen desaturation, hallucinations and PONV was recorded.

Fully awake patients, with stable vital signs for 30 min, no bleeding, no pain or no nausea or vomiting were considered ready for discharge from PACU and PACU stay time was recorded.

\section{Statistical Analysis}

Descriptive inferential statistical analysis has been carried out. Analysis of variance (ANOVA) and student " $t$ " test is used to find significance of study parameters on continuous scale within each group and Chi-square test to find significance of study parameters on categorical scale between two or more groups.

\section{Results}

The three groups were comparable in distribution of age, gender and ASA physical status. (Table 1) There was no statistically significant difference in the duration of anaesthesia, surgery, emergence time and extubation time. (Table 2)

Table 1: Demographic distribution of patients

\begin{tabular}{|c|c|c|c|c|}
\hline Parameter & Group A & Group B & Group C & $\mathbf{p}$ \\
\hline $\begin{array}{c}\text { Age } \\
\text { (years) }\end{array}$ & $4.76 \pm 2.34$ & $4.53 \pm 2.58$ & $5.87 \pm 3.43$ & 1.000 \\
\hline $\begin{array}{c}\text { Gender } \\
\text { (male/female) }\end{array}$ & $34 / 4$ & $32 / 6$ & $29 / 9$ & 0.350 \\
\hline $\begin{array}{c}\text { ASA status } \\
\text { (grade1/2) }\end{array}$ & $36 / 2$ & $32 / 6$ & $36 / 2$ & 0.213 \\
\hline
\end{tabular}


Table 2: Comparison of durations

\begin{tabular}{|c|c|c|c|c|}
\hline $\begin{array}{c}\text { Parameter } \\
\text { (min) }\end{array}$ & Group A & Group B & Group C & $\mathbf{p}$ \\
\hline $\begin{array}{c}\text { Mean duration } \\
\text { of surgery }\end{array}$ & $49.89 \pm 24.12$ & $42.76 \pm 21.01$ & $49.63 \pm 27.59$ & 0.355 \\
\hline $\begin{array}{c}\text { Mean } \\
\text { anaesthesia } \\
\text { duration }\end{array}$ & $74.07 \pm 26.93$ & $65.97 \pm 23.72$ & $74.57 \pm 28.69$ & 0.288 \\
\hline $\begin{array}{c}\text { Time to } \\
\text { extubation }\end{array}$ & $7.68 \pm 2.56$ & $7.53 \pm 2.55$ & $8.00 \pm 3.28$ & 0.758 \\
\hline $\begin{array}{c}\text { Emergence } \\
\text { time }\end{array}$ & $3.05 \pm 2.29$ & $2.34 \pm 0.85$ & $2.87 \pm 1.26$ & 0.133 \\
\hline PACU stay & $75.79 \pm 6.83$ & $74.21 \pm 7.03$ & $71.58 \pm 7.72$ & 0.040 \\
\hline
\end{tabular}

The mean duration of PACU stay was significantly less in Group C. On comparing mean duration of PACU stay between groups, groups A and $B(p=0.606)$ and groups $B$ and $C(p=0.253)$ were statistically similar, but significant difference was noted between groups $A$ and $C(p=0.032)$.

Table 3: Comparison of emergence agitation

\begin{tabular}{|c|c|c|c|c|}
\hline EA & Group A & Group B & Group C & Total \\
\hline No & $26(68.4 \%)$ & $13(34.2 \%)$ & $27(71.1 \%)$ & $66(57.9 \%)$ \\
\hline Yes & $12(31.6 \%)$ & $\mathbf{2 5 ( 6 5 . 8 \% )}$ & $11(28.9 \%)$ & $\mathbf{4 8 ( 4 2 . 1 \% )}$ \\
\hline Total & $38(100 \%)$ & $38(100 \%)$ & $38(100 \%)$ & $114(100 \%)$ \\
\hline
\end{tabular}

The number of children who developed EA in group B was statistically significant with $\mathrm{p}<0.001$ when compared to group A and C. Significant difference existed between groups $\mathrm{A}$ and $\mathrm{B}$ and groups $\mathrm{B}$ and $\mathrm{C}$, but groups $\mathrm{A}$ and $\mathrm{C}$ were statistically similar (Group A-Group B: $\mathrm{p}=0.003$, Group A-Group C: $\mathrm{p}=0.803$, Group B-Group C: $\mathrm{p}=0.001)$. (Table 3 )

Table 4: Comparison of rescue medications given after EA in the three groups

\begin{tabular}{|c|c|c|c|c|}
\hline $\begin{array}{c}\text { Rescue } \\
\text { medicatio } \\
\text { ns }\end{array}$ & Group A & Group B & Group C & Total \\
\hline No & $26(68.4 \%)$ & $13(34.2 \%)$ & $27(71.1 \%)$ & $66(57.9 \%)$ \\
\hline Yes & $12(31.6 \%)$ & $25(65.8 \%)$ & $11(28.9 \%)$ & $48(42.1 \%)$ \\
\hline Total & $38(100 \%)$ & $38(100 \%)$ & $38(100 \%)$ & $114(100 \%)$ \\
\hline
\end{tabular}

The requirement of rescue medication after EA was found to be significantly more in Group B with $\mathrm{p}<0.001 *$. (Table 4)

None of the patients had PONV, respiratory depression or desaturation.

Table 5: Comparison of various study outcome variables according to EA (Yes/No)

\begin{tabular}{|c|c|c|c|c|}
\hline & Group A & Group B & Group C & $\begin{array}{l}\text { Total } \\
(n=114)\end{array}$ \\
\hline \multicolumn{5}{|c|}{ Age in years } \\
\hline Without EA & $5.08 \pm 2.61$ & $5.31 \pm 2.75$ & $6.37 \pm 3.62$ & $5.65 \pm 3.1$ \\
\hline With EA & $4.08 \pm 1.51$ & $4.12 \pm 2.44$ & $4.64 \pm 2.66$ & $4.23 \pm 2.26$ \\
\hline$p$ value & 0.229 & 0.181 & 0.160 & $0.008^{*}$ \\
\hline \multicolumn{5}{|c|}{ Duration of surgery (min) } \\
\hline Without EA & $47.69 \pm 22.06$ & $38.85 \pm 18.16$ & $47.44 \pm 25.25$ & $45.85 \pm 22.7$ \\
\hline With EA & $54.67 \pm 28.55$ & $44.8 \pm 22.43$ & $55 \pm 33.39$ & $49.6 \pm 26.66$ \\
\hline$p$ value & 0.415 & 0.415 & 0.452 & 0.420 \\
\hline \multicolumn{5}{|c|}{ Duration of anaesthesia (min) } \\
\hline Without EA & $71.15 \pm 24.67$ & $63.85 \pm 21.52$ & $71.52 \pm 27.67$ & $69.86 \pm 25.2$ \\
\hline With EA & $80.42 \pm 31.51$ & $67.08 \pm 25.13$ & $82.09 \pm 31.11$ & $73.85 \pm 28.5$ \\
\hline$p$ value & 0.331 & 0.696 & 0.309 & 0.431 \\
\hline \multicolumn{5}{|c|}{ Time to extubation (min) } \\
\hline Without EA & $7.73 \pm 2.65$ & $7.69 \pm 2.21$ & $7.56 \pm 3.57$ & $7.65 \pm 2.95$ \\
\hline With EA & $7.58 \pm 2.47$ & $7.44 \pm 2.75$ & $9.09 \pm 2.21$ & $7.85 \pm 2.61$ \\
\hline$p$ value & 0.871 & 0.777 & 0.195 & 0.705 \\
\hline \multicolumn{5}{|c|}{ Time to consciousness/ emergence(min) } \\
\hline Without EA & $3.12 \pm 2.63$ & $2.15 \pm 0.8$ & $2.93 \pm 1.36$ & $2.85 \pm 1.91$ \\
\hline With EA & $2.92 \pm 1.38$ & $2.44 \pm 0.87$ & $2.73 \pm 1.01$ & $2.63 \pm 1.04$ \\
\hline$p$ value & 0.807 & 0.330 & 0.664 & 0.464 \\
\hline \multicolumn{5}{|c|}{ Duration of PACU stay(min) } \\
\hline Without EA & $72.31 \pm 4.06$ & $68.46 \pm 4.74$ & $69.63 \pm 6.34$ & $70.45 \pm 5.39$ \\
\hline With EA & $83.33 \pm 5.37$ & $77.2 \pm 6.14$ & $76.36 \pm 8.97$ & $78.54 \pm 7.14$ \\
\hline$p$ value & $<0.001^{*}$ & $<0.001^{*}$ & $0.013^{*}$ & $<0.001^{*}$ \\
\hline \multicolumn{5}{|c|}{ EA maximum time lasted (min) } \\
\hline With EA & $12.5 \pm 2.61$ & $11.4 \pm 3.07$ & $10 \pm 4.47$ & $11.35 \pm 3.38$ \\
\hline \multirow[t]{2}{*}{$p$ value } & Group A-B & Group A-C & Group B-C & \\
\hline & 0.619 & 0.183 & 0.483 & \\
\hline
\end{tabular}


The incidence of EA in the total population was significantly high in mean age of $4.23 \pm 2.26 \mathrm{yrs}$.

Duration of PACU stay was prolonged in children with EA in all the groups.

It was noted to be statistically similar, when maximum duration of EA was compared between the three groups (groups $\mathrm{A} \& \mathrm{~B}, \mathrm{p}=0.619$, groups $\mathrm{A} \& \mathrm{C} \mathrm{p}=0.183$, groups $\mathrm{B} \& \mathrm{C}, \mathrm{p}=0.483$ ).

\section{Discussion}

EA is described as a transient phenomenon of dissociated state of consciousness in which the child is irritable, non-compromising, uncooperative, incoherent and inconsolably crying, moaning and kicking. ${ }^{1}$ Sevoflurane is the inhalational anaesthetic agent of choice in paediatric age group due to its non-irritant nature, low blood gas solubility coefficient causing rapid induction and greater haemodynamic stability. ${ }^{3}$

Central nervous system irritation, neurotoxic influence of degradation products and imbalance between synaptic inhibition and excitation have been speculated to cause EA. ${ }^{\mathbf{1 , 4 5}}$

A variety of factors may play a role in the development of EA such as anaesthesia related (rapid emergence, insoluble anaesthetics), adjuvant medications (benzodiazepines, opioids, anti-cholinergics), head -neck, tonsils, thyroid, eye surgery, pain and patient related (age, preoperative anxiety, child temperament). ${ }^{3}$

Ketamine has been used successfully to reduce the incidence of EA. Lee et $\mathrm{al}^{6}$ compared ketamine $0.25 \mathrm{mg} / \mathrm{kg}$ and $0.5 \mathrm{mg} / \mathrm{kg}$ i.v. administered $10 \mathrm{~min}$ before the end of surgery and reported a decrease in incidence of EA due to the combined analgesic and sedative effect. They also noted lower pain scores with the higher dose of ketamine and suggested that increasing the ketamine dose was effective as an analgesic without delaying the recovery. The results of the present study are similar to this.

We administered the study drug at induction of anaesthesia, as followed by Eqhbal et $\mathrm{al}^{7}$ who administered ketamine $0.25 \mathrm{mg} / \mathrm{kg}$ i.v. during induction of anaesthesia and observed that low- dose ketamine was effective in reducing EA and postoperative pain.

Abu-Shahwan et $\mathrm{al}^{8}$ and Dalens et $\mathrm{al}^{9}$ reported that ketamine $0.25 \mathrm{mg} / \mathrm{kg}$ at end of surgery reduced emergence agitation in children under sevoflurane anaesthesia without a delay in recovery.

However, study done by Chen et $\mathrm{al}^{\mathbf{1 0}}$ showed conflicting results. They demonstrated that administration of $0.25 \mathrm{mg} / \mathrm{kg}$ ketamine with $0.5 \mathrm{mcg} / \mathrm{kg}$ of fentanyl prior to the end of sevoflurane-remifentanil based anaesthesia was not effective in reducing EA in non-premedicated children who underwent cataract surgery, compared to either $0.05 \mathrm{mg} / \mathrm{kg}$ midazolam or $1 \mathrm{mg} / \mathrm{kg}$ propofol in combination with $0.5 \mathrm{mcg} / \mathrm{kg}$ of fentanyl.

This could be attributed to different anaesthetic techniques and premedicants used, and use of maximum dose for ketamine by Chen et al.

Kawaraguchi et al ${ }^{\mathbf{1 1}}$ reported that administration of ketamine $1 \mathrm{mg} / \mathrm{kg}$ after the induction of anaesthesia followed by infusion of ketamine $1 \mathrm{mg} / \mathrm{kg} / \mathrm{hr}$ during paediatric strabismus surgery succeeded in decreasing EA.

Kararmaz et al $^{12}$ administered a relatively high dose of oral ketamine $(6 \mathrm{mg} / \mathrm{kg})$ and reported reduced incidence of EA in children undergoing adenotonsillectomy after desflurane anaesthesia without a delay in recovery.

Fentanyl is a widely used potent opioid receptor agonist effective in reducing EA. Cohen EA et $\mathrm{al}^{13}$ found concurrent use of fentanyl during induction with sevoflurane in a dose of $2.5 \mathrm{mcg} / \mathrm{kg}$ resulted in a low incidence of EA in children receiving sevoflurane or desflurane anaesthesia. Cravero et $\mathrm{al}^{\mathbf{1 4}}$ showed that addition of fentanyl $1 \mathrm{mcg} / \mathrm{kg} 10 \mathrm{~min}$ before discontinuation of sevoflurane decreased incidence of postoperative agitation from $56 \%$ to $12 \%$ in children scheduled for magnetic resonance imaging scans without any surgical intervention.

Similarly, Kim et $\mathrm{al}^{\mathbf{1 5}}$ demonstrated that use of both fentanyl $1 \mathrm{mcg} / \mathrm{kg}$ i.v. and propofol $1 \mathrm{mg} / \mathrm{kg}$ 
at the end of sevoflurane anaesthesia effectively reduced the incidence of EA in children undergoing ambulatory inguinal hernia repair. In another investigation, Inomata et $\mathrm{al}^{16}$ observed that a bolus of $2 \mathrm{mcg} / \mathrm{kg}$ fentanyl followed by an infusion of $1 \mathrm{mcg} / \mathrm{kg} / \mathrm{hr}$ prevented emergence in children anaesthetized with sevoflurane.

Though we have taken leads from earlier studies, our study differs in its design, patient population, and the dosage, route and timing of administration of study drugs and criteria used to assess EA.

We found higher incidence of EA in preschool children confirming the revelation made by Aono et $\mathrm{al}^{17}$ that psychological immaturity of preschool children and their inability to express themselves, coupled with the rapid awakening in a strange environment, may have been the main cause of increased incidence of EA in preschool boys, after sevoflurane anaesthesia.

Considering the study by Fazi et $\mathrm{al}^{18}$ who reported that the use of premedication, such as midazolam, reduced the incidence of EA, we opted for midazolam as the rescue medication.

The time interval for measuring the incidence of EA, which is an important factor, was chosen to be a minimum of 1 hour in PACU in this study, according to results of Cole et $\mathrm{al}^{3}$ who found that agitation is at its peak in the first 30 minutes.

It is often difficult to distinguish between postoperative pain and EA in younger children as symptoms of both might be similar. Therefore, different assessments tools have been used by different investigators to differentiate between the two. Although postoperative pain is regarded as a contributing factor in the aetiology of $\mathrm{EA}^{\mathbf{1}}$, there are many supporting reports of increased EA after sevoflurane anaesthesia, in pain-free children where regional or parenteral analgesia has been administered. ${ }^{\mathbf{1 , 6}, 17}$ Therefore, pain cannot be considered as the sole contributing factor to EA.

However, pain was probably not a contributing factor in the incidence of EA in the current study, as multi-modal analgesia was administered to the patient, to take care of the surgical pain.
It was observed that mean duration of PACU stay was prolonged in ketamine and fentanyl $2 \mathrm{mcg} / \mathrm{kg}$ groups. Also, period of stay in PACU was lesser in patients who did not have EA in all 3 groups, when compared to those who had EA. This was in contrast to several studies which documented that time to reach discharge criteria was unchanged by the addition of either small dose of fentany $1^{14}$ and ketamine $e^{6,19}$ during sevoflurane general anaesthesia when compared with placebo. This significant prolongation of PACU stay noted in ketamine group despite less incidence of EA and other adverse effects could be attributed to logistic problems and other unavoidable extraneous factors like non-availability of trolley, non-availability of ward nurse to accompany the patient, delay in settlement of bills etc.

The positive effect of parental presence was observed by Aouad et $\mathrm{al}^{\mathbf{2 0}}$ who related the low incidence of EA in children to the parental presence in the PACU. Considering this, parents were allowed to be present in the preoperative area as well as in the PACU.

\section{Limitations}

We did not use PAED or CHEOPS scale as Aono's scale was easily applicable. PONV and respiratory depression were assessed only during PACU stay. Logistic problems and extraneous factors like nonavailability of trolley, ward nurse, delay in settlement of bills etc. were not taken into consideration during discharge from PACU.

Further studies are needed comparing the time of administration of drugs -at the beginning or end of surgery.

\section{Conclusion}

Administration of either ketamine $0.5 \mathrm{mg} / \mathrm{kg}$ or fentanyl $3 \mathrm{mcg} / \mathrm{kg}$ intravenously at the time of induction reduced the incidence of emergence agitation with no delay in recovery, when compared with fentanyl $2 \mathrm{mcg} / \mathrm{kg}$.

\section{References}

1. Vlajkovic GP, Sindjelic RP. Emergence delirium in children: Many questions, few answers. Anesth Analg.2007;104:84-91 http://dx.doi.org/10.1213/01.ane.0000250914.9188 
$\underline{1 . \mathrm{a} 8}$

PMid:17179249

2. Uezono S, Goto T, Terui K, Ichinose F, Ishguro Y, Nakata Y, et al. Emergence agitation after sevoflurane versus propofol in pediatric patients. AnesthAnalg.2000;91:563-6 http://dx.doi.org/10.1213/00000539-20000900000012

PMid:10960377

3. Lerman J. Sevoflurane in pediatric anesthesia. AnesthAnalg. 1995;81:S4-S10 http://dx.doi.org/10.1097/00000539-199512001$\underline{00002}$

PMid:7486147

4. Adachi M, Ikemoto $\mathrm{Y}$, Kubo K, Takuma C. Seizure-like movements during induction of anaesthesia with sevoflurane. $\mathrm{Br} J$ Anaesth 1992;68:214 -15

http://dx.doi.org/10.1093/bja/68.2.214

PMid:1540467

5. Yli-Hankala A, Vakkuri A, Sarkela M, et al. Epileptiform electroencephalogram during mask induction of anesthesia with sevoflurane. Anesthesiology 1999;91:1596-603 http://dx.doi.org/10.1097/00000542-199912000$\underline{00009}$

PMid:10598599

6. Lee YS, Kim WY, Choi JH, Son JH, Kim JH, Park YC. The effect of ketamine on the incidence of emergence agitation in children undergoing tonsillectomy and adenoidectomy under sevoflurane general anesthesia. Korean $J$ Anaesthesiol.2010;58:440-5

http://dx.doi.org/10.4097/kjae.2010.58.5.440

PMid:20532051 PMCid:PMC2881518

7. Eqhbal MH, Tareqh S, Amin A, Sahmeddini MA. Ketamine improves postoperative pain and emergence agitation following adenotonsillectomy in children: A randomized clinical trial. Middle East J Anesthesiol. 2013 Jun;22(2):155-60

8. Abu-Shahwan I, Chowdary K. Ketamine is effective in decreasing the incidence of emergence agitation in children undergoing dental repair under sevoflurane general anesthesia. Pediatr Anesth. 2007; 17:846-50.

http://dx.doi.org/10.1111/j.1460-

9592.2007.02298.x

PMid: 17683402

9. Dalens BJ, Pinard AM, Létourneau DR, Albert NT, Truchon RJ. Prevention of emergence agitation after sevoflurane anesthesia for pediatric cerebral magnetic resonance imaging by small doses of ketamine or nalbuphine administered just before discontinuing anesthesia. Anesth Analg. 2006;102:1056-61

http://dx.doi.org/10.1213/01.ane.0000200282.3804 $\underline{1.1 \mathrm{f}}$

PMid:16551898

10. Chen J, Li W, Hu X, Wang D. Emergence agitation after cataract surgery in children: A comparison of midazolam, propofol and ketamine. Pediatr Anesth 2010;20:873-9

http://dx.doi.org/10.1111/j.1460-

9592.2010.03375.x

PMid:20716081

11. Kawaraguchi Y, Miyamoto Y, Fukumitsu K, Taniguch i A, Hirao O, Kitamura S, et al. The effect of ketamine on reducing post operative agitation after sevoflurane anesthesia in pediatric strabismus surgery. Masui. 2002; 51: 1343-8 PMid: 12607270

12. Kararmaz A, Kaya S, Turhanoglu S, Ozyilmaz MA. Oral ketamine premedication can prevent emergence agitation in children after desflurane anesthesia. Pediatr Anesth. 2004;14:477-82 http://dx.doi.org/10.1111/j.1460-

9592.2004.01224.x

PMid:15153210

13. Cohen IT, Finkel JC, Hannallah RS, Hummer KA, Patel KM. The effect of fentanyl on the emergence characteristics after desflurane or sevoflurane anesthesia in children. Anesth Analg. 2002;94:1178-81.

http://dx.doi.org/10.1097/00000539-200205000$\underline{00023}$

PMid:11973185

14. Cravero JP, Beach M, Dodge CP, Whalen K. Emergence characteristics of sevoflurane compared to halothane in pediatric patients undergoing bilateral pressure equalization tube insertion. J Clin An esth 2000;12:397-401 http://dx.doi.org/10.1016/S0952-8180(00)00180-X

15. Kim MS, Moon BE, Kim H, Lee JR. Comparison of propofol and fentanyl administered at the end of anesthesia for prevention of emergence agitation after sevoflurane anesthesia in children. $\mathrm{Br} J$ Anesth. 2013;110:274-80

http://dx.doi.org/10.1093/bja/aes382 PMid:23103775

16. Inomata $S$, Maeda $T$, Shimizu $T$, Satsumae $T$, Tanaka M. Effects of fentanyl infusion on tracheal intubation and emergence agitation in preschool children anaesthetized with sevoflurane. $\mathrm{Br} J$ Anesth. 2010;105:361-7 http://dx.doi.org/10.1093/bja/aeq168 PMid:20627877

17. Aono J, Ueda W, Mamiya K, Takimoto E, Manabe M. Greater incidence of delirium during recovery from sevoflurane anesthesia in preschool boys. Anesthesiology. 1997;87:1298-300 
http://dx.doi.org/10.1097/00000542-199712000-

$\underline{00006}$

PMid:9416712

18. Fazi L, Jantzen EC, Rose JB, Kurth CD, Watcha MF. A comparison of oral clonidine and oral midazolam as preanesthetic medications in the pediatric tonsillectomy patient. Anesth Analg. 2001;92:56-61

http://dx.doi.org/10.1097/00000539-200101000-

$\underline{00011}$

PMid:11133600

19. Dahmani S, Stany I, Brasher C, Lejeune C, Bruneau B, Wood C, et al. Pharmacological prevention of sevoflurane and desflurane related emergence agitation in children: A meta-analysis of published studies. Br J Anesth. 2010;104:21623

http://dx.doi.org/10.1093/bja/aep376

PMid:20047899

20. Aouad MT, Kanazi GE, Siddik-Sayyid SM, Gerges FJ, Rizk LB, Baraka AS. Preoperative caudal block prevents emergence agitation in children following sevoflurane anesthesia. Acta Anesthesia Scand. 2005;49:300-4

http://dx.doi.org/10.1111/j.1399-

$\underline{\text { 6576.2005.00642.x }}$

PMid:15752392 